\title{
Secondary School Mathematics Teachers' Use of Students' Learning Styles When Teaching Functions: A Case of Zimbabwean Schools
}

\author{
Edmore Mangwende ${ }^{1^{*}}$, Aneshkumar Maharaj ${ }^{2}$ \\ ${ }^{1}$ Vengere High School, Rusape, ZIMBABWE \\ 2 University of Kwazulu-Natal, Durban, SOUTH AFRICA
}

Received 18 December 2017 - Revised 24 April 2018 • Accepted 5 May 2018

\begin{abstract}
This paper reports on a research that was done to explore how ordinary level mathematics teachers used their knowledge of their students' learning styles when teaching functions. The study was carried out at eight secondary schools in the Makoni District of Manicaland Province in Zimbabwe. The schools were selected using stratified random sampling. Twenty-five mathematics teachers at the selected schools participated in the research. Data were obtained through face to face interviews and document analysis. The findings revealed that the mathematics teachers' teaching and assessment strategies were not based on their knowledge of their students' learning styles. Information and communication technology (ICT) and audio teaching aids were not used by most of the teachers. The researchers recommended that the mathematics teachers be in-serviced on the implications of students' learning styles for mathematics teaching. The teachers also needed some in-service training on how to use different forms of ICT in mathematics teaching.
\end{abstract}

Keywords: functions, mathematics teachers, students' learning styles, teaching strategies

\section{INTRODUCTION}

In our opinion, mathematics teaching should be informed by teachers' knowledge of students' learning styles. Full knowledge of students' learning styles could help mathematics teachers in planning instruction that suits all students. A study carried out in South Africa revealed that although teachers acknowledged that learners have different learning styles, their practice did not match what they reported (Matseke, 2013). Teachers preferred teaching in ways they were taught or the way they preferred learning (Patel \& Singh, 2014). Haas (2003) reported that mathematics classrooms were largely verbal environments in which instructions were given verbally with follow ups done on the chalkboard. The environment forced students to memorise formulae, algorithms and theorems. Such an environment is suitable only for students with strong processing skills.

The purpose of the current research study was to explore how mathematics teachers in Zimbabwe used their knowledge of their students' learning styles when teaching functions to ordinary level mathematics students. The researchers chose to carry out the study on the teaching of functions because they considered functions as the backbone of advanced level mathematics. Haas (2003) supported this by reiterating that the understanding of the theories of functions is vital in enabling students to understand advanced mathematics.

Haas (2003) defined a function as a mapping or an operator relating an input set of numbers to an output set of numbers so that each element of the input set is related to only one element of the output set. The input set is called the domain set and the output set is referred to as the codomain set. Denbel (2015) asserted that functions can be in different representations. The representations include graphs, mapping diagrams, verbal statements, tables and notations like $f: x \rightarrow y$ or $f(x)=y$.

(C) 2018 by the authors; licensee Modestum Ltd., UK. This article is an open access article distributed under the terms and conditions of the Creative Commons Attribution License (http://creativecommons.org/licenses/by/4.0/). $\square$ mangwendeeddy@gmail.com (*Correspondence) $\square$ maharaja@ukzn.ac.za 


\section{Contribution of this paper to the literature}

- To present to the world how the mathematics teachers use their knowledge of their students' learning styles in teaching functions.

- $\quad$ The results revealed that the mathematics teachers rarely use ICT in mathematics teaching.

- Some mismatch existed between the teacher's teaching strategies and the students' learning styles.

When teaching functions, the Ministry of Primary and Secondary Education (MOPSE) Mathematics Syllabus in Zimbabwe for Forms 1-4 (2015) stated that teachers should assess the students' abilities to do the following;

1. Apply mathematical symbols, terms and definitions.

2. Draw and interpret tables, graphs, charts and diagrams accurately.

3. Make effective use of a variety of information and communication technology system tools in solving problems.

4. Solve routine and non-routine problems using appropriate formulae, algorithms and procedures.

\section{Research Question}

The current research was guided by the following research question: How do secondary school mathematics teachers use their knowledge of students' learning styles in teaching functions in mathematics? To help answer this research question, the following sub-questions were formulated:

1. What are the teaching strategies used by mathematics teachers when teaching functions?

2. What are the teaching aids used by the teachers when teaching functions?

3. How do the teachers assess their students' progress in learning functions?

\section{LITERATURE REVIEW}

Al-balhan (2007) defined learning style as the most comfortable way a learner can learn. It is the learner's preferred way of learning. Barke (2009) argued that learning styles are an integration of cognitive processes and learner behaviour. Learners have different learning styles. Differences exist in the way information is perceived, processed and communicated by learners (Barke, 2009; Felder, 2010; Patel \& Singh, 2014; Powell \& Powell, 2016).

Research on learning styles led to learners being categorised in many ways (Abuzaid, Nadarajan, \& Naimie, 2016; Honey \& Mumford, 1986; Kolb \& Kolb, 2005).One of the ways of classifying learners based on their learning styles was given by Perini, Silver and Strong (2000). Perini, Silver, and Strong classified mathematics learners as shown in Table 1. 
Table 1. Classification of mathematics learners (Perini, Silver \& Strong, 2000)

\begin{tabular}{|c|c|c|}
\hline Class of learner & Description & $\begin{array}{l}\text { Preferred learning } \\
\text { activities }\end{array}$ \\
\hline $\begin{array}{l}\text { Mastery maths } \\
\text { learners }\end{array}$ & $\begin{array}{l}\text { - Learn in a step by step manner } \\
\text { - Enjoy solving problems by following algorithms, theorems and formulae } \\
\text { - Have difficulties in solving non-routine problems } \\
\text { - Prefer teachers who coach them } \\
\text { - Judge learning by clarity and practicality of the concepts learnt }\end{array}$ & $\begin{array}{l}\text { Application of algorithms, } \\
\text { formulae and theorems }\end{array}$ \\
\hline $\begin{array}{l}\text { Interpersonal } \\
\text { maths learners }\end{array}$ & $\begin{array}{l}\text { - Learn through dialogue and collaboration } \\
\text { - } \text { Are interested in how mathematics concepts help in real life } \\
\text { - Have difficulties in solving problems as individuals } \\
\text { - Do not like solving problems that do not have real life application } \\
\text { - Want teachers who appreciate their successes and struggles } \\
\text { - Judge mathematics learning by its potential to help people }\end{array}$ & $\begin{array}{l}\text { Group } \\
\text { discussions }\end{array}$ \\
\hline $\begin{array}{l}\text { Understanding } \\
\text { maths learners }\end{array}$ & $\begin{array}{l}\text { - Seek to understand why mathematics concepts learnt work } \\
\text { - Like problems that allow them to prove and explain reasons for taking certain } \\
\text { decisions } \\
\text { - Seek patterns in mathematics concepts } \\
\text { - Have difficulties in working with others in solving problems } \\
\text { - Judge learning by use of evidence and logic }\end{array}$ & $\begin{array}{l}\text { Proving why concepts work } \\
\text { in real life } \\
\text { working as individuals in } \\
\text { solving problems }\end{array}$ \\
\hline $\begin{array}{l}\text { Self-expressive } \\
\text { maths learners }\end{array}$ & $\begin{array}{l}\text { - Use imaginations to solve mathematics tasks } \\
\text { - Enjoy solving non-routine problems } \\
\text { - Generate possible solutions by exploring alternatives } \\
\text { - Judge learning by originality of the concepts learnt }\end{array}$ & $\begin{array}{l}\text { Solving non-routine and } \\
\text { project-like mathematics } \\
\text { problems }\end{array}$ \\
\hline
\end{tabular}

Due to the diverse nature of students' learning, Perini, Silver, and Strong (2000) advised mathematics teachers to use a variety of teaching strategies. According to Perini et al., students should be assisted in recognising their learning styles through the use of four dimensions of mathematics learning. The four dimensions are computation, explanation, application and problem solving. It is important for mathematics teachers to align teaching and assessment strategies with students' learning styles as they go through the four dimensions of mathematics learning. Dasari (2006) reinforced the need to align teaching strategies and students' learning styles by saying that students retain information longer if they are taught in their preferred learning style.

Bender and Waller (2011) advocated differentiated teaching to ensure that all learners benefit from the learning process. Differentiated teaching as defined by Tomlinson (2001) entails tailoring instruction so as to meet individual needs of the learners. Laura (2017) added by saying differentiated teaching means the teacher observes and understands differences and similarities among students and uses the information to plan instruction. Weselby (2017) summarised differentiated teaching as designing a lesson based on students' learning styles. According to Weselby, differentiated teaching involves continuous formative assessment and adjustment of lesson content until it meets students' needs. Tomlinson (2001) suggested that differentiated teaching can be done in three areas of teaching which are content (what the learner learns), process (how the content is mastered by the learner) and product (how the learning process is assessed and evaluated).

Umugiraneza and Bansilal (2017) purported that the most common strategies used in mathematics learning are direct instruction, cooperative learning and problem based instruction. Moore (2012) proposed alternative mathematics learning strategies which included manipulation of objects, real life application of mathematics concepts, integration of information and communication technology devices and use of games. Moore emphasised on the use of games in mathematics learning by saying games help in developing mathematical thinking. On the other hand, White (2012) noted that the use of manipulatives like drawing instruments and computers create more concrete representations of mathematical concepts in learners than any other method. The Ministry of Primary and Secondary Education (MOPSE) Mathematics Syllabus in Zimbabwe for Forms 1-4 (2015) suggested the following teaching strategies to be used in teaching mathematics concepts: discussions, expositions, demonstrations, simulations, educational tours and presentations by experts. The MOPSE syllabus suggested that mathematics teachers use relevant texts, information and communication technology tools, the environment, braille materials, talking tools and software when teaching mathematics.

Yousuf and Behlol (2015) supported the use of information and communication technology (ICT) systems when teaching mathematics by reporting that the application of ICT as a teaching strategy was found to be effective as compared to traditional strategies. ICT as defined by Mohanty (2011), refers to all technological tools and resources used to communicate, create, disseminate, store and manage information. It includes computers, the internet, broadcasting technologies (radio and television), cell phones and calculators. Mohanty proclaimed that ICT has many benefits to students. One of the benefits is that it gives students an opportunity to collaborate on assignments 
Table 2. Demographic information of the mathematics teachers $(n=25)$

\begin{tabular}{ccccccccc}
\hline & \multicolumn{2}{c}{ Teaching experience in years } & \multicolumn{4}{c}{ Highest professional qualifications } \\
\cline { 2 - 8 } & Less than $\mathbf{5}$ & Between $\mathbf{5}$ and $\mathbf{1 0}$ & More than $\mathbf{1 0}$ & None & Diploma & Bachelor's degree & Master's degree \\
\hline Females & 2 & 2 & 4 & 1 & 4 & 3 & 0 \\
\hline Males & 3 & 6 & 8 & 3 & 10 & 2 & 2 \\
\hline Total & 5 & 8 & 12 & 4 & 14 & 5 & 2 \\
\hline
\end{tabular}

with people inside and outside school through flexibility of anywhere, anytime access. Tinker (2017) reported that computer software packages were used in schools in Mathematics teaching. Tinker noted that the widely used packages in teaching functions were ClarisWorks, Microsoft works, Alice and Stella. However, a study carried out in Ghana revealed that mathematics teachers did not integrate ICT in their mathematics instruction (Agyei \& Voogt, 2010). According to Agyei and Voogt, the mathematics teachers in Ghana lacked knowledge about how ICT can be integrated in mathematics teaching.

Apart from teaching methods that are student centred and sensitive to students' learning styles, assessment of the learning process is also a very important aspect in learning mathematics concepts like functions. Boaler (2016) proposed assessment that focuses on improving understanding of mathematics concepts. Boaler reiterated that mistakes made by students should present a powerful learning opportunity which teachers should take advantage of by providing immediate feedback on students' actions and how the actions can be improved.

The analysis of the literature on mathematics teaching indicated that the teaching of functions at ordinary level calls for teaching and assessment strategies that take into consideration the differences in students' learning styles.

\section{MATERIALS AND METHODS}

Data used in this research were obtained from twenty five mathematics teachers at eight secondary schools in the Makoni District of Manicaland Province in Zimbabwe. The schools were selected using stratified random sampling method. This was done to ensure that the sample included schools under different responsible authorities. Black (1999) supported the use of stratified random sampling by saying that stratified random sampling ensures that groups are proportionally represented in the sample. All mathematics teachers at the selected schools participated in the research. 2.

The demographic information of the mathematics teachers who participated in the research is shown in Table

Permission to carry out the research was sought from the Zimbabwean office of the Permanent Secretary in The Ministry of Primary and Secondary Education as well as from Manicaland Provincial Education Director. At school level, the researcher got permission from school heads before meeting the mathematics teachers. The mathematics teachers were given a participant information sheet which explained the purpose of the research and the rights of the participants. The teachers were asked to fill in a consent form before participating in the research. The researchers clearly explained to the mathematics teachers that their participation in the research was voluntary.

Data were collected through face to face interviews. Document analysis was then done to triangulate the data obtained through the face to face interviews. The documents analysed were the mathematics teachers' schemes of work and lesson plans. An interview guide and a document analysis checklist were prepared in advance. An interview session took not more than thirty minutes. Audio recorders were used to help in capturing data during the face to face interviews. Statements given by the teachers during the interviews were transcribed verbatim.

The data collected were analysed qualitatively. During data cleaning, similar statements from the teachers were used to develop themes. The themes were then used in data analysis. Verbatim statements made by the teachers were used to support and illustrate the research findings.

\section{FINDINGS}

\section{Teaching Strategies used by the Mathematics Teachers when Teaching Functions}

The data obtained from the mathematics teachers revealed that all the participants used both individual and group activities when teaching functions. Further information obtained from the teachers' schemes of work indicated that the teachers used groups of not more than three students during group work sessions. However, group work was used on rare cases as shown by the teachers' lesson plans. When asked to comment on the effectiveness of group work in teaching functions, one of the teachers said:

"Students get an opportunity to suggest what they consider solutions to given problems unlike in situations where they learn as individuals or as the whole class. I normally do not use group work due 
Table 3. Activities done by students during lessons on functions ( $n=126$ lessons)

\begin{tabular}{lcc}
\hline Activities & Frequencies & Percentages \\
\hline Identifying patterns & 5 & $3.97 \%$ \\
\hline Applying learnt concepts in solving everyday life problems & 52 & $41.27 \%$ \\
\hline Using imaginations in solving real life problems involving functions & 6 & $4.76 \%$ \\
\hline Drawing, sketching and plotting graphs of functions & 107 & $84.92 \%$ \\
\hline Solving non-routine problems involving functions & 7 & $2.56 \%$ \\
\hline Solving project-like questions involving functions & 27 & 13 \\
\hline Locating points on Cartesian planes & 13 & $10.32 \%$ \\
\hline Using graphs of functions to estimate values & 7 & $5.56 \%$ \\
\hline
\end{tabular}

Table 4. Reasons given by the teachers for not using ICT in teaching functions ( $n=25$ teachers)

\begin{tabular}{lcc}
\hline Reasons & Frequencies & Percentages \\
\hline Lack of time & 5 & $20 \%$ \\
\hline Teacher not computer literate & 17 & $68 \%$ \\
\hline Lack of availability of the needed equipment & 19 & $76 \%$ \\
\hline Lack of training on using ICT in mathematics teaching & 13 & $52 \%$ \\
\hline No constant supply of electricity & 5 & $20 \%$ \\
\hline School authority not supportive & 2 & $8 \%$ \\
\hline Negative attitude on the part of the teacher & 2 & $8 \%$ \\
\hline
\end{tabular}

to shortage of time. Thirty five minutes allocated to a mathematics lesson is not enough for me to use group work effectively. It is difficult to get feedback from the students. I propose that the lessons be allocated up to an hour. Imagine students want to make a table of values for the function $f(x)=x 3+5$, draw the graph to a given scale and then give feedback to the class. It cannot be done in thirty five minutes." (Ms A, pers.com).

Data obtained from one hundred and twenty-six lessons that were analysed revealed that the mathematics teachers used the activities shown in Table 3 when teaching functions at ordinary level.

Twenty one teachers $(84 \%)$ indicated that they rarely gave non-routine and project-like questions to their students. One of the teachers said:

\begin{abstract}
"Non-routine and project-like questions are time consuming and challenging. I do not think my students are able to solve these questions. I do not give these problems to my students. However, with the newly introduced curriculum, there is no way out. I have to find time for the questions." $(\mathrm{Mr} B$, pers.com).
\end{abstract}

\title{
Teaching Aids used by the Mathematics Teachers in Teaching Functions
}

The use of ICT in teaching functions was not common in all the schools that were sampled. Calculators were the only electronic device used in all the schools. Only one teacher indicated that he sometimes used computers in teaching functions. The teacher said:

\begin{abstract}
"My students enjoy learning through the use of computer systems. I sometimes ask them to use excel in drawing graphs. For instance, if you check on the exercise that I gave on Monday. I asked the students to draw bar graphs showing marks they obtained in this month's tests. Each student had to show his or her marks on a bar graph." (Mr C, pers.com).
\end{abstract}

The reasons given by the teachers for not using ICT in their lessons on functions were as indicated in Table 4. Commenting on the use of ICT in mathematics teaching, one of the teachers had the following to say:

"I need to learn to use the computer. The students are far ahead of us in terms of technology. How can I try to use ICT in my lessons when the students know better than me? I will end up embarrassing myself." (Mr D, pers. com).

The data obtained from the teachers revealed that all the mathematics teachers who participated in this research did not use audio teaching aids. In one hundred and seven (84.92\%) lessons planned, the teachers wanted their students to draw graphs and diagrams from given functions. The students used rulers, protractors and compasses. Visual aids were a common feature in ninety-one lessons $(72.22 \%)$ planned by the teachers. The visual aids included charts with graphs, question strips and chalkboard with exercises or diagrams. Sixteen teachers $(64 \%)$ had the view 
Table 5. Skills assessed by the mathematics teachers and how the skills were assessed

\begin{tabular}{|c|c|c|c|c|}
\hline MOPSE skill & $\begin{array}{l}\text { Examples of tasks done by students (taken from } \\
\text { the teachers' lesson plans) }\end{array}$ & $\begin{array}{l}\text { Group work } \\
\text { or individual } \\
\text { work }\end{array}$ & $\begin{array}{l}\text { Class of learners } \\
\text { catered for }\end{array}$ & $\begin{array}{l}\text { Estimated } \\
\text { time } \\
\text { given }\end{array}$ \\
\hline $\begin{array}{c}\text { Applying mathematical } \\
\text { symbols, terms and } \\
\text { definitions } \\
\end{array}$ & \multirow{3}{*}{$\begin{array}{l}\text { Given } \\
f(x)=x^{2}+2 \text { for } \\
x \in \mathbb{Z} \\
\text { (i) construct a table of values for }-2 \leq x \leq 8 \\
\text { (ii)draw the graph of the function for the given } \\
\text { domain using a scale of } 2 \mathrm{~cm} \text { representing } 1 \text { unit on } \\
\text { both axes } \\
\text { (ii) using the graph, find the minimum value of } f(x)\end{array}$} & \multirow{3}{*}{ Individual work } & \multirow[t]{3}{*}{$\begin{array}{l}\text { Understanding maths } \\
\text { learners and mastery } \\
\text { maths learners }\end{array}$} & \multirow{3}{*}{25 minutes } \\
\hline $\begin{array}{l}\text { Drawing tables and } \\
\text { graphs accurately }\end{array}$ & & & & \\
\hline Interpreting graphs & & & & \\
\hline $\begin{array}{l}\text { Making effective use of } \\
\text { information and } \\
\text { communication } \\
\text { technology system } \\
\text { tools in solving } \\
\text { problems } \\
\end{array}$ & $\begin{array}{l}\text { Using excel, draw a bar graph of the marks that } \\
\text { you obtained in your monthly mathematics tests in } \\
2017\end{array}$ & Individual work & $\begin{array}{l}\text { Self-expressive maths } \\
\text { learners and } \\
\text { understanding maths } \\
\text { learners }\end{array}$ & 20 minutes \\
\hline \multirow[t]{2}{*}{$\begin{array}{l}\text { Solving routine and } \\
\text { non-routine problems } \\
\text { using appropriate } \\
\text { formulae, algorithms } \\
\text { and procedures }\end{array}$} & $\begin{array}{l}\text { 1. In pairs, perform the following tasks. } \\
\text { (i) Draw circles with the following radii: } 7 \mathrm{~cm}, 14 \mathrm{~cm} \\
\text { and } 28 \mathrm{~cm} \\
\text { (ii) Using the piece of wire provided, measure and } \\
\text { record the circumferences of the circles } \\
\text { (iii) Divide the circumferences by their respective } \\
\text { radii } \\
\text { (iv) Hence, express the circumference of a circle as } \\
\text { a function of the radius of the circle } \\
\text { (iv) Use the function to calculate the circumference } \\
\text { of a circle with radius } 21 \mathrm{~m} \text { long }\end{array}$ & Group work & $\begin{array}{l}\text { Interpersonal maths } \\
\text { learners, self- } \\
\text { expressive maths } \\
\text { learners and } \\
\text { Mastery maths learners }\end{array}$ & 45 minutes \\
\hline & $\begin{array}{l}\text { 2. The number of goats at a farm is five less than } \\
\text { twice the number of sheep at the farm. Express the } \\
\text { number of goats in terms of the number of sheep. } \\
\text { If there are ten sheep at the farm, how many goats } \\
\text { are at the farm? }\end{array}$ & Individual work & $\begin{array}{l}\text { Understanding maths } \\
\text { learners } \\
\text { and mastery maths } \\
\text { learners }\end{array}$ & 10 minutes \\
\hline $\begin{array}{l}\text { Interpreting graphs } \\
\text { (identifying patterns) }\end{array}$ & $\begin{array}{l}\text { 3. Draw the graphs of the function } f(x)=a x^{2} \\
\text { for } a=2, a=-2 \text {, } \\
a=1 \text { and } a=-1 \\
\text { for }-3<x<3 \text {. Comment on the nature of the } \\
\text { graphs for } a<0 \text { and } a>0\end{array}$ & Individual work & $\begin{array}{l}\text { Understanding maths } \\
\text { students }\end{array}$ & 30 minutes \\
\hline
\end{tabular}

that using visual teaching aids was the most effective way of teaching functions. Five teachers (20\%) indicated that they used visual aids simply because they were readily available in their area as compared to other teaching aids.

\section{How the Mathematics Teachers Assessed their Students' Progress during Lessons on Functions}

Table 5 summaries how the mathematics teachers assessed their students' work on functions.

It was noted that all the teachers used presentations as a way of assessing their students' ability to communicate ideas. The teachers said they gave their students opportunities to present their work to their peers after group discussions. It was however reiterated that not all the students got the opportunity to present due to lack of time. One of the teachers said:

\footnotetext{
"I allow students to work in groups. This enables them to learn to communicate ideas to peers. Due to shortage of time, not all of them get the opportunity to express themselves to their peers. At times we reduce the number of students in a group so that we increase the chances for every student to at least say something."(Mr L.pers.com).

Apart from the skills given in Table 5, the teachers pointed out that they also assessed their students' neatness, accuracy in making calculations, ability to identify mathematical patterns and ability to perform given tasks within given timeframes. Neatness was assessed in the context of graphs and diagrams drawn. The following were statements from some of the teachers:
} 
"I also assess the neatness of the graphs and sketch diagrams drawn by the students. Diagrams should be clear and presentable."(Mr M. pers.com).

"I am very particular about the time my students take in performing given tasks. Time management is very important for my students to pass exams. However it is a case of being fast and accurate. Calculations must be done accurately especially when constructing tables of values." (Ms N.pers.com).

\section{DISCUSSION}

This study revealed that the mathematics teachers used both individual and group work when teaching functions. According to the teachers, group work was rarely used. Perini et al. (2000), affirmed that 'understanding maths learners' learn better if they learn as individuals than in groups while 'interpersonal maths learners' learn better in groups than as individuals. The data obtained from the mathematics teachers exposed that 'interpersonal maths learners' were not fully catered for during lessons on functions. They were denied an opportunity to collaborate in groups. However, since it is not possible to use group work all the time, it is important to get learners to take note that at times they need to also learn in individual settings by reflecting and interacting with the material to be learnt.

The data obtained from the teachers indicated that in most of the lessons on functions, students were instructed to draw, sketch or plot graphs. These activities were in line with the requirements of the Ministry of Primary and Secondary Education Syllabus in Zimbabwe for Forms 1-4 (2015) which stipulated that by the end of the learning period, students should be able to draw and interpret tables, graphs, charts and diagrams accurately. The same syllabus required students to solve non-routine problems on functions. However, twenty-one of the mathematics teachers indicated that they rarely gave non-routine problems to their students. This was a disservice to 'selfexpressive maths students' since they enjoy solving non-routine problems (Perini et al., 2000).

According to Perini et al. (2000), 'understanding maths students' learn by identifying patterns in mathematical concepts. However, only $3.97 \%$ of the lessons planned by the mathematics teachers gave the students an opportunity to identify patterns. The findings of this research also revealed that the mathematics teachers did not use games when teaching functions. Games are regarded as necessary for the students as they develop mathematical thinking in the students (Moore, 2012).

Tinker (2017) indicated that computer software packages like Stella were used in schools in United States of America in mathematics teaching. However, the current research revealed that only one of the mathematics teachers reported using computers when teaching functions. The only electronic gadget used by the teachers in their lessons was an electronic calculator. The results of the current research were similar to those obtained by Agyei and Voogt (2010) in Ghana. Agyei and Voogt observed that mathematics teachers in Ghana did not use computers in mathematics teaching.

According to the mathematics teachers, the students' ability to apply learnt concepts and the ability to communicate ideas were assessed during lessons on functions. It was also noted that students were involved in hands-on activities during the lessons. Students were given an opportunity to draw, plot and sketch graphs of functions. According to Perini, Silver and Strong (2000), these tasks are important for 'mastery maths learners'. The findings exposed that 'self-expressive maths learners' were not fully catered for by the teachers since the teachers rarely gave non-routine exercises to their students.

\section{RECOMMENDATIONS}

Based on the results obtained from the research, the researchers recommend that it is important for mathematics teachers to attend in-service workshops on the implications of students' learning styles on mathematics teaching. It is important for teachers to know the differences in their students' learning styles before planning instructions. This knowledge could help teachers during their lesson preparation to ensure that all students benefit from the planned instruction. Application of differentiated teaching strategies require full knowledge of students' learning styles.

The use of ICT in mathematics teaching cannot be ignored. It was discovered in the research that the teachers did not use ICT mainly because of computer illiteracy and lack of computer resources in schools. It is therefore important for school administrators to acquire ICT devices for use in mathematics lessons. The teachers need training on how to integrate ICT in mathematics teaching.

Mathematics teaching requires the use of a variety of teaching aids so that students of different learning styles benefit. Teachers should vary teaching aids. The researchers recommend that school authorities assist mathematics teachers in acquiring teaching aids for use in mathematics lessons. 


\section{ACKNOWLEDGEMENTS}

The researchers express sincere gratitude to all the mathematics teachers who participated in this research study. The researchers also thank all gate keepers who granted permission to carry out the research.

\section{REFERENCES}

Abuzaid, R. A., Nadarajan, R., \& Naimie, Z. (2016). Do we have salt and pepper on the table? (Teaching styles \& learning styles important). London: Taylor \& Francis Group.

Agyei, D. D., \& Voogt, J. (2010). ICT use in the teaching of mathematics: Implications for professional development of preservice teachers in Ghana. Twente: University of Twente.

Al-balhan, E. M. (2007). Learning styles in relation to academic performance in middle school Mathematics. Middle East: Domes.

Barke, O. P. (2009). Learning styles Knowledge, issues and application for classroom teachers. Amherst: University of Massachusetts.

Bender, W. N., \& Waller, L. (2011). Differentiated Math Instruction. New York: Corwin Press.

Black, T. R. (1999). Doing quantitative research in the social sciences: An integrated approach to research design, measurement, and statistics. Thousand Oaks, CA: SAGE Publications.

Boaler, J. (2016). Mathematical mindsets: Unleashing students' potential through creative Math, inspiring messages and innovative teaching. San Francisco, CA: Jossey-Bass.

Dasari, P. (2006). The influence of mismatching teaching and learning styles on the achievement in Science of grade six learners. Bloemfontein: University of Free State.

Felder, R. M. (2010). Are learning styles invalid on course newsletter? A response to claims that no evidence justifies taking learning styles into account when designing instruction.

Haas, S. C. (2003). Algebra for gifted visual spatial learners. Gifted Education Communicator (spring), 34(1), 30-31; 4243.

Honey, P., \& Mumford, A. (1986). The Manual of Learning Styles. Maidenhead: Peter Honey.

Kolb, A. Y., \& Kolb, D. A. (2005). The Kolb Learning Style Inventory - Version 3.1: 2005 Technical Specifications. Haygroup: Experience Based Learning Systems Inc.

Laura, R. (2017). What is differentiated instruction? New York: Rowan University.

Matseke, A. M. (2013). Capacity Building for curriculum differentiated in the teaching of foundation phase Mathematics in Ngwaritsi Circuit. Limpopo: University of South Africa.

Ministry of Primary and Secondary Education Mathematics syllabus forms 1-4 (2015). Harare: Curriculum Development and Technical Services.

Mohanty, R. R. (2011). ICT advantages and disadvantages. Retrieved on 13 August 2017 from http:/ / www.ict-advdisadv-blogsport.com/2011/02/introduction-to-ict.html

Moore, N. D. (2012). Alternative strategies for teaching Mathematics (M.S. Ed. thesis). Brockport, NY: State University of New $\quad$ York. $\quad$ Retrieved on $22 \quad$ July 2017 from http:/ / digitalcommons.brockport.edu/cgi/viewcontent.cgi?article=1132\&context=ehd_theses

Patel, K. L., \& Singh, S. (2014). Matching and Mismatching of learning styles and teaching styles: A conceptual perspective. Shaikshik Parisamvad (An International Journal of Education), 4, 20-26.

Perini, M. J., Silver, H. F., \& Strong, R. W. (2000). So Each May Learn: Integrating learning styles and multiple intelligences. Alexandria, West Virginia USA: Association for Supervision and Curriculum Development.

Powell, W., \& Powell, O. K. (2016). Knowing our students as learners. Alexandria: ASCD.

Tinker, R. (2017). Information Technology in Science and Mathematics Education. Retrieved on 15 July 2017 from https://concord.org/sites/default/files/pdf/enc-v7.pdf

Tomlinson, C. A. (2001). How to differentiate instruction in mixed-ability classrooms. Alexandria VA: Association for Supervision and Curriculum Development.

Umugiraneza, O., \& Bansilal, S. (2017). Exploring teachers' practices in teaching mathematics and statistics in Kwazulu- Natal schools. South African Journal of Education, 37(2), 1-13. https://doi.org/10.15700/saje.v37n2a1306

Weselby, C. (2017). What is differentiated instruction? Examples of how differentiated instruction in the classroom. Oregon: Concodia University. 
White, K. M. (2012). The effect of an instructional model utilizing hands-on learning and manipulatives on Maths achievement of middle school students in Georgia (Doctoral dissertation). Lynchburg, VA: Liberty University. $\begin{array}{llllll}\text { Retrieved } & \text { on } & 22 & \text { July } & 2017 & \text { from }\end{array}$ http:/ / digitalcommons.liberty.edu/cgi/viewcontent.cgi?article=1653\&context=doctoral

Yousuf, M., \& Behlol, M. G. (2015). Effectiveness of information and communication technology in teaching Mathematics at Secondary level. Islandad. International Islamic University International journal of Academic research, 3(5), 67-72.

\section{http://www.ejmste.com}

